\title{
Pressure Ulcer in Intensive Care Units: a case-control study
}

\author{
Lesão por Pressão em Unidade de Terapia Intensiva: estudo de caso-controle \\ Úlcera por Presión en Unidad de Terapia Intensiva: estudio de caso-control
}

\section{Heloisa Helena Ponchio Pachá', Josimerci Ittavo Lamana Faria', Kleber Aparecido de Oliveira', Lúcia Marinilza Beccaria'}

\author{
' Faculdade de Medicina de São José do Rio Preto. São José do Rio Preto, São Paulo, Brasil.
}

How to cite this article:

Pachá HHP, Faria JIL, Oliveira KA, Beccaria LM. Pressure Ulcer in Intensive Care Units: a study control-case. Rev Bras Enferm [Internet]. 2018;71(6):3027-34. DOI: http://dx.doi.org/10.1590/0034-7167-2017-0950

Submission: 02-14-2018 Approval: 05-25-2018

\begin{abstract}
Objective: To evaluate the relationship between presence/absence of Pressure Ulcer, socio-demographic factors and hospitalization. Method: Case-control study, performed through multiple logistic regression based on information from the adverse event reporting system and the hospital information system, between September/2014 and August/2015. Results: Among the risk factors, after adjustment, age greater than or equal to 60 years, hospitalization due to infectious, parasitic and neoplastic diseases, periods of hospitalization longer than seven days and being hospitalized in ICU other than ICU covenant were highlighted. Most of ulcers were reported with mild damage degree and Stage II classification. Conclusion: Age and days of hospitalization presented a dose-response effect, the longer the age or the number of days of hospitalization, the greater the chances of Pressure Ulcer. There was a significant association among higher occurrences of death in patients with ulcer.
\end{abstract}

Descriptors: Patient Safety; Pressure Ulcer; Intensive Care Unit; Critical Care, Risk Factors.

\section{RESUMO}

Objetivo: Avaliar a relação entre a presença/ausência de Lesão por Pressão e fatores sociodemográficos e da internação. Método: Estudo de caso-controle, realizado por meio de regressão logística múltipla com base em informações dos sistemas de notificação de eventos adversos e do sistema de informação hospitalar, no período entre setembro/2014 e agosto/2015. Resultados: Entre os fatores de risco, destacaram-se, após ajuste, idade maior ou igual 60 anos, internação por doenças infecciosas, parasitárias e neoplasias, períodos de internação maiores que sete dias e estar internado em UTI que não fosse UTI convênio. A maioria das lesões foi notificada com grau de dano leve e classificada em estágio II. Conclusão: A idade e os dias de internação apresentaram efeito dose-resposta, quanto maior a idade ou o número de dias de internação, maiores as chances da presença de Lesão por Pressão. Houve associação significativa entre maior ocorrência de óbitos em pacientes com lesão. Descritores: Segurança do Paciente; Lesão por Pressão; Unidade de Terapia Intensiva; Cuidados Críticos, Fatores de Risco.

\section{RESUMEN}

Objetivo: Evaluar la relación entre la presencia/ausencia de Úlcera por Presión y factores sociodemográficos y de la internación. Método: Estudio de caso-control, realizado por medio de regresión logística múltiple con base en informaciones de los sistemas de notificación de eventos adversos y del sistema de información hospitalaria, en el período entre septiembre/2014 y agosto/2015. Resultados: Entre los factores de riesgo, se destacaron, después de ajuste, edad mayor o igual 60 años, internación por enfermedades infecciosas, parasitarias y neoplasias, períodos de internación mayores que siete días y estar internado en UTI que no fuera UTI convenio. La mayoría de las lesiones fueron notificadas con un grado de daño leve y clasificado en estadio II. Conclusión: La edad y los días de internación presentaron efecto dosis-respuesta, cuanto mayor sea la edad o el número de días de internación, mayores las posibilidades de la presencia de úlcera por Presión. Se observó una asociación significativa entre la mayor ocurrencia de muertes en pacientes con úlcera.

Descriptores: Seguridad del Paciente; Úlcera por Presión; Unidad de Terapia Intensiva; Cuidados Críticos, Factores de Riesgo. 


\section{INTRODUCTION}

Quality care and patient safety have been discussed in the last 15 years in health care, teaching, research and society. The occurrence of adverse events is a serious problem and the damages caused have significant implications on mortality, morbidity, and quality of life, as they negatively affect patients in all health care contexts ${ }^{(1)}$.

Nursing, because it is the largest health workforce in Brazil, refers to the need for a direct relationship between the category and patient safety strategies and the prevention of errors. The reporting of adverse events is necessary, as it contributes to the monitoring and control of occurrences and to the elaboration of more effective preventive measures ${ }^{(2)}$.

The reduction of risks and damages and the introduction of good practices allow the effectiveness of nursing care and its management in a safer way. This depends on a change in the culture of professionals, with a view to safety ${ }^{(3)}$. The verification of good care practices through the nursing audit is an important tool to improve the quality of care provided ${ }^{(4)}$.

Indicators are presented as numerical variables related to the care process. Its use is routine in health institutions, however, it is still necessary to implement analysis strategies so that they are comparable in order to reflect the different contexts of health care ${ }^{(5)}$.

Pressure Ulcer (PU) is considered to be one of the negative indicators of health care and nursing care quality and its prevention is important considering the context of the global movement for patient safety ${ }^{(6)}$.

As defined by the National Pressure Ulcer Advisory Panel National Pressure Ulcer Advisory Panel (NPUAP), PU is defined as localized damage to the underlying skin and/or soft tissue, usually over bone prominence, or related to the use of a medical device or artifact. Ulcer occurs as a result of intense and/or prolonged pressure or pressure combined with shear and may present as whole or as an open ulcer, and be painful. The factors for the development of ulcer are multicausal, soft tissue tolerance to pressure and shear can also be affected by microclimate, nutrition, perfusion, comorbidities and by its condition $^{(7)}$

PU represents a serious problem involving the suffering of people, economic aspects and an interdisciplinary challenge, since it consumes a great amount of resources of the health system and hours of nursing care ${ }^{(8)}$, due to its prolonged treatment and of high $\cos ^{(9)}$.

\section{OBJECTIVE}

This study aims to evaluate the relationship between presence/absence of Pressure Ulcer and socio-demographic factors and hospitalization.

\section{METHOD}

\section{Ethical aspects}

The research was approved by the Research Ethics Committee of the Hospital de Base, Fundação Faculdade Regional de Medicina de São José do Rio Preto - FUNFARME.

\section{Design, place of study and period}

A case-control study was carried out in five Intensive Care Units (ICUs) with 103 beds, from a hospital of special size located northwest of São Paulo State. Data collection was performed between September 2014 and August 2015.

\section{Sample, criteria of exclusion and inclusion}

The sample consisted of 189 patients who were considered as cases and 570 patients considered controls (approximately, three controls for each case). Patients who presented PU during ICU hospitalization and control patients who did not develop were considered as patients. Patients admitted to ICUs participated in the study and patients whose hospitalization occurred before September 2014 were excluded from the study, in addition to patients who were still hospitalized until the end of data collection.

\section{Study protocol}

Data collection was carried out between September 2014 and August 2015, through notifications of occurrences of PU in chips filled in the computerized system, sent to the risk management service. Identification of the notifier (name, profession, work unit), date of registration of the notification, date of event, patient identification (room, bed, hospitalization unit, name and electronic medical record number), type event, description and severity of the damage were in the patient's medical record. Sociodemographic data and the hospitalization of the patient were obtained by the hospital information system.

The number of controls was stipulated by approximately three times the number of cases, consisting of patients hospitalized in the five ICUs during the study period and who did not present PU during hospitalization. Through the information system of the hospital, the patients who were hospitalized in these units were located.

Information about all patients seen in the five ICUs was transferred to an Excel spreadsheet. From this database, the patients who had PU (cases) were removed, leaving those without the complaint (candidates for controls). After these, they were sorted and numbered according to date of hospitalization, which allowed the control to be obtained through a systematic random draw. The total number of patients without ulcer was divided by the necessary amount of controls, producing the sample interval. A number between zero and the sample interval to obtain the casual start was chosen; which corresponded to the number of the first patient selected. This number was added to the sample interval, selecting the second patient and so, successively, until obtaining the sample number approximately three times the number of cases.

For the case and control study, the presence/absence of PU was considered as a dependent variable. The independent variables selected for this analysis were stratified into two sociodemographic dimensions and those related to hospital admission. The sociodemographic variables were: Gender (Male and Female); age in years (less than or equal to 40,41 to 60 , 61 to 80 and equal to or greater than 81); schooling (illiterate to incomplete elementary school, complete elementary school to incomplete high school, complete high school to incomplete higher education, complete higher education or more, do not 
know or did not state); origin (São José do Rio Preto city, regions of São Paulo State or other states).

The ones related to hospital admission were the hospitalization unit (CCU, POU, Insurance ICU, SUS General ICU $5^{\text {th }}$ floor [UTI Geral SUS $5^{\circ}$ andar], SUS General ICU $7^{\text {th }}$ floor [UTI Geral SUS $7^{\circ}$ andar]); medical diagnosis according to the International Classification of Diseases - ICD-10 (Diseases of the system, respiratory circulatory system, digestive and genitourinary, infectious and parasitic diseases and neoplasms, abnormal findings, external causes or consequences, and factors influencing health status; diseases of the nervous system, diseases of the blood, diseases of the endocrine system, mental disorders, diseases of the eye and appendages, musculoskeletal and connective tissue diseases, gestation, childbirth and the puerperium); (up to 7 hospitalization days, 8 to 15 days, 16 to 30 days and greater than 31 days).

The time of hospitalization prior to ICU hospitalization and the diagnosis that the patient presented when hospitalized at these units, although relevant in the studies on Pressure Ulcer, were not considered, and we believe that this is a limitation of this study. This fact occurred due to the data being secondary, obtained in the hospitalization system of the hospital.

The reason for hospitalization and the patient's entry condition in ICU are recorded in the medical and nursing evolution that was not verified in this study. All patients (case group) were admitted to ICU without ulcer, and acquired during ICU admission (they were notified by ICU nurses at the time the PU was identified).

In addition to the case and control study, the relationship between the patient's exit motive (discharge, external transfer or other reasons versus death) and the presence/absence of PU and for the cases were also evaluated. The frequencies of the variables damage (mild, moderate, severe and death) and PU staging (Degree I, II, III, and IV) were calculated.

To determine the severity of the event, the International Classification for Patient Safety of the World Health Organization was used, characterized as no harm to events whose damage is asymptomatic or without detectable symptoms and does not require treatment; mild as symptomatic damage, with mild symptoms, loss of function or minimal or intermediate damage, short duration, without intervention or with a minimal intervention required (e.g, extra observation, survey, analysis or small treatment); as moderate symptomatic damage, requiring intervention, as a supplemental procedure, additional therapy, increase in stay or what caused permanent or long term damage, or loss of functions; as severe symptomatic damage, requiring life-saving intervention or major medical/ surgical intervention, shortening life expectancy or causing great permanent, long-term damage or loss of functions and death as damage caused or anticipated in the short term by the incident ${ }^{(10)}$.

Ulcers can be classified into stages: I - Non-white ulcer erythematous on intact skin, where discoloration, temperature increase, edema or hardening may be indicators. II - The injured surface is disjointed from the epidermis, dermis or both, presenting in an abrasive, blister or shallow deepithelization. III - Tissue loss, affecting area of subcutaneous tissue, which may extend to the fascia. IV - Extensive tissue loss and necrosis of underlying muscles, bones and/or tendons ${ }^{(11-12)}$.

\section{Analysis of results and statistics}

For the development of the case and control study, a bivariate analysis was initially performed between the presence/absence of PU and each of the independent variables considered. Absolute and relative frequencies were obtained for the different covariate categories according to the patients' classification in cases and controls. The Chi-square test was used to evaluate the degree of association between the dependent variable and the independent variables.

Prior to the modeling, the exploratory analysis was performed to evaluate the existence of collinearity between covariables, by calculating the variance inflation factors (VIF) ${ }^{(13)}$, being considered as the upper limit for non-existence of collinearity VIF = 4. Logistic regression was used to identify the best explanatory model for the presence/absence of PU, using as the criterion of choice the one with the lowest Akaike Information Criterium (AIC), among all possible ones. In both bivariate and multiple analyzes, the significance level of $5 \%$ was considered as a criterion for affirming the existence of an association between the dependent variable and the independent variable.

We started with the initial model with all the independent variables. The AICs of this model were calculated, as well as the AIC of the other models, with the exclusion of one of the variables and maintenance of the others. The variable that produced the largest reduction in AIC was excluded in this step. The procedure continued until the exclusion of some variables provoked the increase of the AIC, thus reaching the final model. Once the final model was obtained, the respective gross and adjusted Odds Ratio (OR) values, their 95\% confidence intervals and $p$ values, were calculated for independent variables (according to their categories). All procedures were performed in program $\mathrm{R}$, version 3.2.4 $4^{(13)}$.

\section{RESULTS}

Initially, 199 patients with PU in ICU from a teaching hospital were initially enrolled between September 2014 and August 2015. Of these, eight were excluded because hospitalization had occurred before September 2014, and two were still hospitalized until the end of data collection, and it was not possible to finalize the collection, constituting a sample of 189 patients that were considered as cases. Controls were obtained by means of a systematic random lottery with 4,044 patients hospitalized in the period who did not have ulcer. After the draw, 570 controls were obtained (approximately, three controls for each case).

From the 189 cases, 125 (66.1\%) were males, 97 (51.3\%) aged 61 to 80 years, $98(51.9 \%)$ had incomplete elementary school and 138 (73\% ) were from cities located in São Paulo State, other than São José do Rio Preto, or from other states. According to hospitalization data, 179 (94.7\%) were from SUS - Sistema Único de Saúde (Brazilian Unified Health System) and $101(53.4 \%)$ remained more than 31 days in the ICU. At the time of discharge 120 (63.5\%) had ICD-10 infectious, parasitic and neoplastic diseases, as shown in Table 1. 
Table 1 - Bivariate analysis of the relationship between presence/absence of Pressure Ulcer and independent variables, São José do Rio Preto, São Paulo, Brazil, 2017

\begin{tabular}{|c|c|c|c|c|c|c|}
\hline \multirow{3}{*}{ Variables } & \multirow{3}{*}{ Categories } & \multicolumn{4}{|c|}{ Pressure Ulcer } & \multirow{3}{*}{$\begin{array}{c}p \\
\text { value* }\end{array}$} \\
\hline & & \multicolumn{2}{|c|}{ Present (189) } & \multicolumn{2}{|c|}{ Absent (560) } & \\
\hline & & $\mathbf{n}$ & $\%$ & $n^{\circ}$ & $\%$ & \\
\hline \multirow[t]{2}{*}{ Gender } & Male & 125 & 66.1 & 333 & 58.4 & \\
\hline & Female & 64 & 33.9 & 237 & 41.6 & 0.0729 \\
\hline \multirow[t]{4}{*}{ Age (years) } & $\leq$ to 40 & 17 & 9.0 & 99 & 17.4 & \\
\hline & 41 to 60 & 50 & 26.5 & 177 & 31.1 & \\
\hline & 61 to 80 & 97 & 51.3 & 228 & 40.0 & \\
\hline & $\geq$ to 81 & 25 & 13.2 & 66 & 11.6 & 0.0071 \\
\hline \multirow[t]{5}{*}{ Schooling } & Illiterate to incomplete elementary school & 98 & 51.9 & 278 & 48.8 & \\
\hline & Complete elementary school to incomplete high school & 35 & 18.5 & 63 & 11.1 & \\
\hline & Complete high school to incomplete higher education & 34 & 18.0 & 128 & 22.5 & \\
\hline & Complete higher education or more & 06 & 3.2 & 53 & 9.3 & \\
\hline & Do not know or did not declare & 16 & 8.5 & 48 & 8.4 & 0.0057 \\
\hline \multirow[t]{2}{*}{ Origin } & São José do Rio Preto & 51 & 27.0 & 182 & 31.9 & \\
\hline & Regions of SP or other states & 138 & 73.0 & 388 & 68.1 & 0.2354 \\
\hline \multirow{5}{*}{$\begin{array}{l}\text { Hospitalization } \\
\text { unit }\end{array}$} & Insurance ICU & 10 & 5.3 & 150 & 26.3 & \\
\hline & SUS General ICU, $7^{\text {th }}$ floor & 46 & 24.3 & 128 & 22.5 & \\
\hline & $\mathrm{POU}$ & 19 & 10.1 & 85 & 14.9 & \\
\hline & $\mathrm{CCU}$ & 51 & 27.0 & 125 & 21.9 & \\
\hline & SUS General ICU, $5^{\text {th }}$ floor & 63 & 33.3 & 82 & 14.4 & 0.0000 \\
\hline \multirow[t]{4}{*}{ ICD-10 } & Circulatory, respiratory, digestive and genitourinary systems. & 48 & 25.4 & 275 & 48.2 & \\
\hline & Infectious, parasitic and neoplastic & 120 & 63.5 & 160 & 28.1 & \\
\hline & Abnormal findings, external causes, and factors influencing health status & 16 & 8.5 & 86 & 15.1 & \\
\hline & Others & 5 & 2.6 & 49 & 8.6 & 0.0000 \\
\hline \multirow{4}{*}{$\begin{array}{l}\text { Hospitalization } \\
\text { days }\end{array}$} & $\leq$ to 7 & 9 & 4.8 & 252 & 44.2 & \\
\hline & 8 to 15 & 23 & 12.2 & 181 & 31.8 & \\
\hline & 16 to 30 & 56 & 29.6 & 99 & 17.4 & \\
\hline & $\geq$ to 31 & 101 & 53.4 & 38 & 6.7 & 0.0000 \\
\hline
\end{tabular}

Note: Intensive Care Unit - ICU; Postoperative Unit - POU; Coronary Care Unit - CCU.

Table 1 presents the bivariate analysis between presence/ absence of PU and the covariables considered. There was a significant association, in this analysis, with the reasons for leaving the hospital, age, schooling, hospitalization unit, ICD-10 and hospitalization days. The analysis, using the inflation factor of the variance, showed that there was no collinearity between all covariates considered (VIF <4). Thus, in the multiple analysis, all the variables presented in Table 1 were considered.

After adjustment, the best model (with the lowest AIC value) was composed by the covariables listed in Table 2 (excluding the gender and origin variables, which did not remain in the final model). In this table, the gross and adjusted ORs, their respective $95 \%$ confidence intervals and $p$ values, are presented for the covariables. Of the variables that remained in the final model, they were significantly associated with presence/absence of PU, schooling, age, ICD-10, hospitalization days and hospitalization unit.

Among the categories of schooling, only those with complete elementary school to incomplete high school had, in the adjusted analysis, higher odds of presence of Pressure Ulcer than those with incomplete elementary school or less, with OR
$=2.5(95 \% \mathrm{Cl}: 1.3-4.7)$. We highlight the category of schooling complete higher education or more, with adjusted OR of protection, but with no significant result $(\mathrm{OR}=0.5 ; 95 \% \mathrm{Cl}$ : $0.1-1.7)$. In relation to age, the categories from 61 to 80 years $(\mathrm{OR}=2.6,95 \% \mathrm{Cl}: 1.2-5.6)$ and, especially, 81 years or more $(\mathrm{OR}=3.7,95 \% \mathrm{Cl}: 1.4-9.7)$, with an increase in the chance of occurrence of the outcome, in relation to those aged 40 years or less. A dose-response effect was observed in the relationship between age and Pressure Ulcer, that is, the greater the age the greater the chance of ulcer.

Patients hospitalized with infectious, parasitic and neoplasm diseases presented higher chances of Pressure Ulcer than patients hospitalized with Circulatory, respiratory, digestive and genitourinary systems $(\mathrm{OR}=1.9,95 \% \mathrm{Cl}: 1.1-3.3)$. All categories of hospitalization days were presented as a risk factor for the occurrence of ulcer in relation to the baseline category (up to seven days), with a dose-response effect (increase in hospitalization days and increase in the chance of the illness). All categories of hospitalization units presented an increased chance for the presence of the complaint in relation to the category Insurance ICU (base) (Table 2). 
Table 2 - Multiple adjusted analysis between presence of Pressure Ulcer and independent variables present in the final model*, São José do Rio Preto, São Paulo, Brazil, 2017

\begin{tabular}{|c|c|c|c|c|c|c|}
\hline \multirow{2}{*}{ Variable } & \multicolumn{3}{|c|}{ Gross results } & \multicolumn{3}{|c|}{ Adjusted results } \\
\hline & OR & $95 \%$ IC & $p$ value & OR & $95 \%$ IC & $p$ value \\
\hline Intercept & & & & 0.0 & $0.0-0.0$ & 0.0000 \\
\hline \multicolumn{7}{|l|}{ Schooling } \\
\hline Illiterate to incomplete elementary school & 1 & & & 1 & & \\
\hline Complete elementary school to incomplete high school & 1.6 & $1.0-2.5$ & 0.0595 & 2.5 & $1.3-4.7$ & 0.0072 \\
\hline Complete high school to incomplete higher education & 0.8 & $0.5-1.2$ & 0.2102 & 1.5 & $0.8-2.7$ & 0.2414 \\
\hline Complete higher education or more & 0.3 & $0.1-0.8$ & 0.0109 & 0.5 & $0.1-1.7$ & 0.2589 \\
\hline Do not know or did not declare & 0.9 & $0.5-1.7$ & 0.8575 & 2.2 & $1.0-4.8$ & 0.616 \\
\hline \multicolumn{7}{|l|}{ Age (years) } \\
\hline$\leq$ to 40 & 1 & & & 1 & & \\
\hline 41 to 60 & 1.6 & $0.9-3.0$ & 0.1055 & 1.4 & $0.6-3.0$ & 0.4317 \\
\hline 61 to 80 & 2.5 & $1.4-4.4$ & 0.0017 & 2.6 & $1.2-5.6$ & 0.0156 \\
\hline$\geq$ to 81 & 2.2 & $1.1-4.4$ & 0.0247 & 3.7 & $1.4-9.7$ & 0.0073 \\
\hline \multicolumn{7}{|l|}{ ICD10 } \\
\hline Circulatory, respiratory, digestive and genitourinary systems & 1 & & & 1 & & \\
\hline Infectious, parasitic and neoplastic & 4.3 & $2.9-6.3$ & 0.0000 & 1.9 & $1.1-3.3$ & 0.0000 \\
\hline $\begin{array}{l}\text { Abnormal findings, external causes, and factors influencing } \\
\text { health status }\end{array}$ & 1.1 & $0.6-2.0$ & 0.8390 & 1.2 & $0.6-2.7$ & 0.5939 \\
\hline Others & 0.6 & $0.2-1.5$ & 0.2780 & 0.9 & $0.3-3.0$ & 0.9043 \\
\hline \multicolumn{7}{|l|}{ Hospitalization days } \\
\hline$\leq$ to 7 dias & 1 & & & 1 & & \\
\hline 8 to 15 & 3.6 & 1.6-7.9 & 0.0017 & 2.9 & $1.3-6.5$ & 0.0110 \\
\hline 16 to 30 & 15.8 & 7.6-33.2 & 0.0000 & 11.6 & $5.4-25.2$ & 0.0000 \\
\hline$\geq$ to 31 & 74.4 & $34.7-159.5$ & 0.0000 & 61.0 & $26.9-138.4$ & 0.0000 \\
\hline \multicolumn{7}{|l|}{ Hospitalization unit } \\
\hline Insurance ICU & 1 & & & 1 & & \\
\hline SUS General ICU 7th floor & 5.4 & $2.6-11.1$ & 0.0000 & 4.2 & $1.7-9.9$ & 0.0013 \\
\hline $\mathrm{POU}$ & 3.4 & $1.5-7.5$ & 0.0034 & 3.1 & $1.2-8.3$ & 0.0243 \\
\hline $\mathrm{CCU}$ & 6.1 & $3.0-12.6$ & 0.0000 & 5.2 & $2.2-17.1$ & 0.0002 \\
\hline SUS General ICU 5th floor & 11.5 & $5.6-23.7$ & 0.0000 & 7.2 & $3.0-17.1$ & 0.0000 \\
\hline
\end{tabular}

Note: Odds Ratio-OR, Information Criterion -IC; Intensive Care Unit -ICU, Postoperative Unit -POU; Coronary Care Unit -CCU.

The presence/absence of PU was significantly associated ( $p<0.0000$ ) with the reason for leaving the hospital. While $61.4 \%(116 / 189)$ of the patients with PU presence died, this proportion was $25.6 \%$ (140/560) in patients without ulcer. Table 3 presents the absolute and relative frequencies of the variables damage and staging for patients with PU.

Table 3 - Pressure Ulcer characterization, São José do Rio Preto, São Paulo, Brazil, 2017

\begin{tabular}{ccc}
\hline Ulcer characteristics & $\mathbf{n}$ & $\mathbf{\%}$ \\
\hline Stage I & 10 & 5.3 \\
Stage II & 178 & 94.2 \\
Stage III & 01 & 0.5 \\
Stage IV & - & - \\
Degree of damage & & \\
Mild & 167 & 88.3 \\
Moderate & 20 & 10.6 \\
Severe & 02 & 1.1 \\
Total & 189 & $100 \%$ \\
\end{tabular}

It can be observed in Table 3 that, of the 189 patients reported, nurses considered $88.3 \%$ degree of mild, $10.6 \%$ moderate and $1.1 \%$ severe damage. Regarding staging of the ulcer, according to who reported, $5.3 \%$ were in stage I, $94.2 \%$ in the II, $0.5 \%$ in the III and none in stage IV.

\section{DISCUSSION}

Intensive care patients generally present a high risk for PU development due to the use of respiratory equipment, urinary catheters, sequential compression devices, multiple intravenous catheters, and infusion of vasoactive drugs ${ }^{(14)}$, and mainly to the reduction of sensory perception caused by sedatives, analgesics and muscle relaxants, resulting in a lower reaction to excessive pressure $^{(11)}$. The incidence of PU in patients admitted to ICU ranges from $11 \%^{(15)}, 22 \%^{(16)}, 35.2 \%^{(17)}$ to $41.5 \%^{(11)}$.

Regarding the gender-independent variable, this study found no statistically significant differences between male and female genders. The difference found in men and women should be due to differences in age, schooling, ICD, hospitalization days and hospitalization unit. The study pointed to the presence of higher PU among men 
$(64.7 \%)$ than in women $(35.3 \%)^{(18)}$. It is likely that the lower demand for health services among men favors their hospitalization in ICUs, also for complications of chronic diseases, sometimes undiagnosed. Generally, women, because they seek more health services, maintain their clinical conditions more stable ${ }^{(19)}$.

Schooling, although shown to be associated with PU in the bivariate analysis, did not present as a risk factor after adjustment for the other covariates in the multivariate analysis. However, another study found association between the occurrence of PU and less schooling ${ }^{(16)}$.

After adjustment, we observed an association between PU and advanced age, and the occurrence of infectious, parasitic and neoplastic diseases. Elderly patients with associated comorbidities present decreased immunity, which leads to infections ${ }^{(20)}$ and those affected by neoplastic diseases, due to the adverse effects of the necessary therapy and disease progression, leading to malnutrition and dehydration ${ }^{(21)}$. As to age, the highest risk encounter in older patients for PU is congruent with other studies ${ }^{(21-22)}$.

The variable hospitalization unit presented a significant result being the largest occurrence in general ICUs SUS. The fact that the ICU is a protective factor for the absence of PU can be related to the clinical picture of the patients, as a rule, less severe in relation to the other ICUs.

Prolonged hospitalization time is recognized as one of the risk factors for PU ${ }^{(11)}$. A study showed that time greater than 10 days in ICU is a factor strongly associated with PU ${ }^{(17)}$, which is in line with the results of the present study, which observed a dose-response effect between increased hospitalization days and greater chances of occurrence of PU. A study conducted in Ohio (USA), with 7,790 ICU patients, showed a significantly longer mean stay of patients who had PU (12.8 days) than those who did not present $(9.7 \text { days })^{(23)}$. Research conducted in public ICU of Greece showed that length of stay and increasing age were significant predictors for the development of PU. The prolonged rest in the ICU bed is highlighted, which reduces the mobility of the patients, increasing the risk of the disease ${ }^{(24)}$.

The significant association between patients with PU and death found in this study may be related to the reason for hospitalization and ulcer occurrence. A study conducted in US hospitals estimated that approximately 600,000 patients die every year due to complications secondary to $\mathrm{PU}^{(25)}$. Prolonged hospitalization time in ICU and infirmary is associated with a higher hospital death rate. It is known that there have been hospitalizations of an increasing number of elderly patients with multiple comorbidities who are frequently submitted to prolonged and debilitating treatments. A study carried out in a public/private university hospital showed that septic shock was the main cause of hospital death after discharge from the Intensive Care Unit ${ }^{(26)}$.

Other factors deserve to be explored, such as the workload, since the study shows a relationship with the occurrence of other adverse events ${ }^{(27)}$, or effectiveness of patient care.

The severity and clinical conditions that the patients present in addition to ICU stay, zero diet, hematological profile, metabolic and comorbidities would also be factors possibly associated with the presence of PU, which deserve to be investigated. In addition, intrinsic and extrinsic factors are relevant for the management of care and service ${ }^{(16)}$.
There was a higher prevalence of stage II ulcers similar to the survey performed at a general hospital in the city of JoinvilleSC. This found $58.5 \%$ of the ulcers identified in stage II. It is possible that this fact is due to the difficulty in distinguishing the reactive erythema from the non-reactive erythema, which al ready constitutes the pre-ulcer and may evolve to later stages if the causal stimulus is not eliminated ${ }^{(11)}$.

Regarding the damage degree caused by PU, no related studies were found. It is important to note that in this study, although the findings show a higher occurrence of II staging, most of the damage was classified as mild. It is known that its occurrence prolongs hospitalization and treatment costs, increases the risk for the development of other complications, such as infections, impairs patient recovery and represents an increase in emotional and physical suffering ${ }^{(28)}$.

$\mathrm{PU}$ acquired at the hospital is associated with increased morbidity and mortality, and is considered as largely avoidable. Its prevalence is considered a marker of health care quality ${ }^{(29)}$. It is imperative that the nurse perform a rigorous control of the hospitalization days of the patient in ICU. Once he is hemodynamically stabilized, a change of position and removal of the bed should be performed as early as possible. It is also necessary to register the appearance of PU and to enable the professionals involved to act in the prevention ${ }^{(21)}$.

Other studies call attention to prevention, such as the one carried out in the Netherlands, there was a statistical association between the process of PU prevention and the occurrence of skin ulcer. The prevalence of PU is related to the quality of care, and measuring this process indicator may provide information for future changes ${ }^{(30)}$. $\mathrm{PU}$ prevention is essential to improve the survival of ICU patients and it is up to health professionals to identify the risk in order to effectively prevent prevention through multiprofessional teamwork and acquisition of materials and pressure relief equipment ${ }^{(23)}$.

It is important to emphasize the importance of the multidisciplinary team in the prevention and treatment of PU in the elderly and it poses a challenge for the professional and the health system to reduce its incidence, taking into account the aging of the population, and the continuing education of the multiprofessional team is fundamental for a qualified care to be achieved ${ }^{(31)}$.

As a strong point to carry out this research, the hospital's information system, electronic medical record and the computerized security incident reporting, which facilitates the collection of data and studies.

\section{Study limitations}

As a limitation, the possibility of underreporting occurred. The length of hospital stay prior to admission to the ICU and the diagnosis that the patient had on admission at this unit, although they were important risk factors in the studies on Pressure Ulcer, were not considered in the present study. We consider this to be a limitation of this study.

\section{Contributions to the sector of Nursing}

The results of this study may contribute to the improvement of nursing care if the services consider them for the implementation of preventive measures, especially for elderly patients with prolonged stay in ICU. 


\section{CONCLUSION}

Among the factors considered as risk for the presence of $\mathrm{PU}$, after adjustment were the age of 60 years or more, hospitalization for infectious, parasitic and neoplastic diseases, periods of hospitalization longer than seven days, and hospitalization for ICU was not the Insurance ICU. Age and hospitalization days showed dose-response effect, the greater the age or the number of hospitalization days, the greater the chances of the presence of PU. There was also a significant association between higher occurrences of death in patients with ulcer.

\section{REFERENCES}

1. National Patient Safety Foundation. Livres de danos: acelerar a melhoria da segurança do paciente quinze anos depois de To Err Is Human. Boston: National Patient Safety Foundation; 2016.

2. Duarte SCM, Stipp MA, Silva MM, Oliveira FT. Adverse events and safety in nursing care. Rev Bras Enferm[Internet]. 2015[cited 2017 Sep 12];68(1):144-54. Available from: http://dx.doi.org/10.1590/0034-7167.2015680120p

3. Oliveira RM, Leitão IMTA, Silva LMS, Figueiredo SV, Sampaio RL, Gondim MM. Estratégias para promover segurança do paciente: da identificação dos riscos às práticas baseadas em evidências. Esc Anna Nery[Internet]. 2014[cited 2017 Sep 12];18(1):122-9. Available from: http://dx.doi.org/10.5935/1414-8145.20140018

4. Ribeiro BS, Silva MC. Auditoria de enfermagem e sua importância no ambiente hospitalar: uma revisão de literatura. Refaci[Internet] 2017[cited 2017 Sep 12];2(2):1-25. Available from: http://revista.faciplac.edu.br/index.php/REFACI/article/view/269/88

5. Rossaneis MA, Gabriel CS, Haddad MCL, Melo MRAC, Bernardes A. Indicadores de qualidade utilizados nos serviços de enfermagem de hospitais de ensino. Rev Eletrôn Enferm[Internet]. 2014[cited 2017 Sep 12];16(4):769-76. Available from: https://doi.org/10.5216/ ree.v16i4.22956

6. Simão CMF, Caliri MHL, Santos CB. Concordância entre enfermeiros quanto ao risco dos pacientes para úlcera por pressão. Acta Paul Enferm[Internet]. 2013[cited 2017 Sep 12];26(1):30-5. Available from: http://dx.doi.org/10.1590/S0103-21002013000100006

7. National Pressure Ulcer Advisory Panel-NPUAP. About-us[Internet]. Washington: NPUAP; 2016[cited 2017 Sep 12]. Available from: http://www.npuap.org/about-us/

8. Rogenski NMB, Kurcgant P. Avaliação da concordância na aplicação da Escala de Braden interobservadores. Acta Paul Enferm[Internet] 2012[cited 2017 Sep 12];25(1):24-8. Available from: http://www.scielo.br/pdf/ape/v25n1/v25n1a05.pdf

9. Moore ZE, Webster J, Samuriwo R. Wound-care teams for preventing and treating pressure ulcers. Cochrane Data base Syst Rev[Internet]. 2015[cited 2017 Sep 12];(9):CD011011. Available from: http://dx.doi.org/10.1002/14651858.CD011011.pub2

10. World Health Organization-WHO. Conceptual framework for the international classification for patient safety. Final Technical Report[Internet]. Geneva (SUI):World Health Organization; 2009[cited 2018 Mar 26]. 154 p. Available from: http://www.who.int/ patientsafety/taxonomy/icps_full_report.pdf

11. Moro A, Maurici A, Valle JB, Zaclikevis VR, Kleinubing Jr HK. Avaliação dos pacientes portadores de lesão por pressão internados em hospital geral. Rev Assoc Med Bras[Internet]. 2007[cited 2017 Sep 12];53(4):300-4. Available from: http://dx.doi.org/10.1590/ S0104-42302007000400013

12. Edsberg LE, Black JM, Goldberg M, Mcnichol L, Moore L, Sieggreen M. Revised national pressure ulcer advisory panel pressure injury staging system. J Wound Ostomy Continence Nurs[Internet]. 2016[cited 2017 Sep 12];43(6):585-97. Available from: http:// dx.doi.org/10.1097/WON.0000000000000281

13. Zuur AF, leno EN, Elphick CS. A protocol for data exploration to avoid common statistical problems. Method Ecol Evolut[Internet]. 2010[cited 2017 Sep 12];1:3-14. Available from: http://dx.doi.org/10.1111/j.2041-210X.2009.00001.x

14. Cooper KL. Evidence-Based Prevention of Pressure Ulcers in the Intensive Care Unit. Crit Care Nurse[Internet]. 2013[cited 2017 Sep 12];33(6):57-68. Available from: http://ccn.aacnjournals.org/content/33/6/57.full.pdf + html

15. Campanili TCGF, Santos VLCG, Strazzieri-Pulido KC, Thomaz PBM, Nogueira PC. Incidence of pressure ulcers in cardiopulmonary intensive care unit patients. Rev Esc Enferm USP[Internet]. 2015[cited 2017 Sep 12];49(Esp):7-13. Available from: http://dx.doi. org/10.1590/S0080-623420150000700002

16. Borghardt AT, Prado TN, Bicudo SDS, Castro DS, Bringuente MEO. Pressure ulcers in critically ill patients: incidence and associated factors. Rev Bras Enferm[Internet]. 2016[cited 2017 Sep 12];69(3):460-7. Available from: http://dx.doi.org/10.1590/0034-7167.2016690307i

17. Gomes FSL, Bastos MAR, Matozinhos FP, Temponi HR, Meléndez GV. Fatores associados à úlcera por pressão em pacientes internados nos Centros de Terapia Intensiva de Adultos. Rev Esc Enferm USP[Internet]. 2010[cited 2017 Sep 12];44(4):1070-6. Available from: http://dx.doi.org/10.1590/S0080-62342010000400031

18. Fernandes LM, Silva L, Oliveira JLC, Souza VS, Nicola AL. Associação entre predição para lesão por pressão e marcadores bioquímicos. Rev Rene[Internet]. 2016[cited 2017 Sep 12];17(4):490-7. Available from: http://dx.doi.org/10.15253/2175-6783.2016000400008 
19. Barcelos RA, Tavares DMS. Fatores associados aos incidentes de segurança entre idosos em terapia intensiva. Acta Paul Enferm[Internet]. 2017[cited 2017 Sep 12];30(2):159-67. Available from: http://dx.doi.org/10.1590/1982-0194201700025

20. Lucena AF, Santos CT, Pereira AGS, Almeida MA, Dias VLM, Friedrich MA. Perfil clínico e diagnósticos de enfermagem de pacientes em risco para úlcera por pressão. Rev Latino-Am Enfermagem[Internet]. 2011[cited 2017 Sep 12];19(3):1-8. Available from: http:// www.scielo.br/pdf/rlae/v19n3/pt_11.pdf

21. Santos CT, Oliveira MC, Pereira AGS, Suzuki LM, Lucena AF. Indicador de Qualidade assistencial de úlcera por pressão: análise de prontuário e de notificação de incidente. Rev Gaúcha Enferm[Internet]. 2013[cited 2017 Sep 12];34(1):111-8. Available from: http://dx.doi.org/10.1590/S1983-14472013000100014

22. Freitas JPC, Alberti LR. Aplicação da Escala de Braden em domicílio: incidência e fatores associados a úlcera por pressão. Acta Paul Enferm[Internet]. 2013[cited 2017 Sep 12];26(6):515-21. Available from: http://dx.doi.org/10.1590/S0103-21002013000600002

23. Hyun S, Vermillion B, Newton C, Fall M, Li X, Kaewprag P, et al. Predictive validity of the Braden Scale for patients in intensive care units. Am J Crit Care[Internet] 2013[cited 2017 Sep 12];22(6):514-20. Available from: http://dx.doi.org/10.4037/ajcc2013991

24. Tsaras K, Chatzi M, Kleisiaris CF, Fradelos EC, Kourkouta L, Papathanasiou IV. Pressure ulcers: developing clinical indicators in evidence based practice: a prospective study. Med Arch[Internet]. 2016[cited 2017 Sep 12];70(5):379-83 Available from: http:// dx.doi.org/10.5455/medarh.2016.70.379-383

25. Brasil. Ministério da Saúde. Agência Nacional de Vigilância Sanitária. Programa Nacional de Segurança do Paciente. Protocolo para prevenção de úlcera por pressão. Brasília (DF): Fiocruz; 2013.

26. Giacomini MG, Lopes MVCA, Gandolfi JV, Lobo SMA. Choque séptico: importante causa de morte hospitalar após alta da unidade de terapia intensiva. Rev Bras Ter Intensiva[Internet]. 2015[cited 2017 Sep 12];27(1):51-6. Available from: http://dx.doi. org/10.5935/0103-507X.20150009

27. Cuadros KC, Padilha KG, Toffoletto MC, Henriquez-Roldán C, Canales MAJ. Patient Safety Incidents and Nursing Workload. Rev Latino-Am Enfermagem[Internet]. 2017[cited 2017 Sep 12];25:e2841. Available from: http://www.scielo.br/pdf/rlae/v25/pt_01041169-rlae-25-e2841.pdf

28. Dantas ALM, Ferreira PC, Valença CN, Diniz KD, Nunes JP, Germano RM. Complicações das úlceras por pressão para o paciente grave: estudo descritivo-exploratório. O Braz J Nurs[Internet]. 2013[cited 2017 Sep 12];12(2):1-7. Available from: http://www. objnursing.uff.br/index.php/nursing/rt/printerFriendly/3794/html_2

29. Coyer F, Miles S, Gosley S, Fulbrook P, Sketcher-Baker K, Cook JL, et al. Pressure injury prevalence in intensive care versus nonintensive care patients: a state-wide comparison. Aust Crit Care[Internet]. 2017[cited 2017 Sep 12];30(5):244-50. Available from: http://dx.doi.org/10.1016/j.aucc.2016.12.003

30. Van Dishoeck AM, Looman CWN, Steyerberg EW, Halfens RJG, Mackenbach JP. Performance indicators: the association between the quality of preventive care and the prevalence of hospital-acquired skin lesions in adult hospital patients. J Adv Nurs[Internet]. 2016[cited 2017 Sep 12];72(11):2818-30. Available from: http://dx.doi.org/10.1111/jan.13044

31. Matozinhos FP, Velasquez-Melendez G, Tiensoli SD, Moreira AD, Gomes FSL. Factors associated with the incidence of pressure ulcer during hospital stay. Rev Esc Enferm USP[Internet]. 2017[cited 2017 Sep 12];51:e03223. Available from: http://dx.doi. org/10.1590/S1980-220X2016015803223 